\title{
Second World War History: Memory Conflict and Dialogue
}

\author{
Dagmara Beitnere-Le Galla
}

Institute of Philosophy and Sociology, University of Latvia, Latvia

Copyright $\bigcirc 2016$ by authors, all rights reserved. Authors agree that this article remains permanently open access under the terms of the Creative Commons Attribution License 4.0 International License

\begin{abstract}
We live in the present, but the past, history and memory accompany us both visibly and invisibly. As stated by Paul Ricoeur, our past 'I' (as opposed to our present 'I', which, due to its experience, is different from our past ' $I$ ') is different from but still the same 'I' (the one that has retained its identity over time). Our identity is created not only by the experience of ourselves, our family and our relatives: we are also influenced by the big historical narratives. More and less recent history - even the big, over-arching events of history influences each one of us, whether directly or indirectly. The paper focuses on two memory groups that "meet" in the Latvian capital, Riga, every year on March 16th and May 9th. These groups represent two collective memories, each of which reflects different views of history and politics, and each corresponds to specific social needs. After the restoration of Latvian independence, and especially in the past decade, the political significance of these two dates has increased. Both dates commemorate events associated with the Second World War - on March 16th Latvians commemorate the soldiers who fought in the Latvian Legion, while the Russian community celebrates Victory Day on May 9th according to the Russian tradition. Every year, these two events remind us that "the war has ended, but the memory war still continues", that the past is not really past and its influence on the present still sometimes creates unexpected "obstructions". The paper analyses such elements of group memory as territory, language and traditions in an attempt to find answers regarding different symbolic values by analysing the life stories of two participants in the Second World War and trying to create a hypothetical dialogue between them.
\end{abstract}

Keywords Collective Remembering, Legionnaires, Occupation, Life Story, Remembering, Forgiveness

\section{20th-century Memories in Latvian History}

Both world wars crossed Latvia, leaving not only destruction in their wake, but also a violent break in people's memories and their commemoration of the dead.

In his voluminous study Bloodlands [1], historian Timothy Snyder makes very precise observations about history. These are important to Eastern European societies, because they acknowledge the repeated occupations of their territories by both the Nazi and Communist regimes, during which both emotional and physical violence were practised, here where the rule and evil of the Nazi and Soviet regimes overlap and interact [2]. Like many other Eastern European countries, Latvia experienced a three-fold occupation: first by the Russians in 1940, then by the Germans in 1941, and again by the Russians in 1944. It was a traumatic experience that began with the loss of national independence in 1940, when the Soviet Union occupied Latvia and destroyed its army leadership. As the Second World War began, the Latvian army was partially incorporated into the Red Army. The Geneva Convention was again violated when German forces occupied Latvia and, beginning in 1943, formed the Latvian Legion. The Convention was once again violated in 1944, when the front line reached Latvia and Russia supplemented its armed forces with Latvian draftees. According to Snyder, during the Second World War, the bloodlands were subjected to not only one invasion, but two or three - not just one occupation regime, but two or three [3]. The loss of nationhood and its citizens' violent incorporation into two warring armies is a part of Latvians' experience, an experience that was either distorted or silenced after the war in Soviet-occupied Latvia.

Latvian citizens were forced to fight in foreign armies during the Second World War, some in German uniforms, others in Soviet uniforms. Among the latter were the so-called Latvian Division soldiers who went to the front lines along with the Soviet army, which retreated as the German army invaded Latvia in 1941. Both occupying forces did as they wished with Latvia's young men, even with those who sympathised with the Soviet system as bringers of truth and equality. Latvian soldiers who had fought in the Red Army and those Legionnaires who had survived the war and Stalin's penal camps received social and memory reconciliation only in 1989 [4] . 
For the whole post-war period, the Soviet system of memory culture isolated those who had fought in various armies; former soldiers were forced to keep silent about their pasts, because anyone who had fought in the Legion was sent to Stalin's penal camps in Siberia. Those who had survived and returned to Latvia were forced to endure further humiliation by not being allowed to live in their former homes or work in their professions and also experiencing indirect repression. But those who had fought on the Soviet side also received no special privileges or provisions, because for the rest of their lives they had to confirm their loyalty to the Soviet system. Unlike elsewhere, Khrushchev's visit to Latvia in 1959 did not initiate a "thaw"; instead, as a result of his visit the nationally-oriented political elite was undermined, distrust in it was expressed, and Moscow introduced a number of controls on Latvian Communists and those who had fought in the war. The Latvian Communists' disappointment was, however, expressed in memoir literature, which was published only after the restoration of Latvian independence in the early 1990s [5]. Repressed and untold memories united soldiers who had been pulled into the armies of both totalitarian regimes and had fought against each other [6], and a new page in collective remembering was opened that united the memories of Legionnaires repressed by the Soviet system and those disillusioned by the Communist regime. Collective remembering took on a multi-layered narrative, but the various experiences nevertheless preserved their group descriptions and defined characteristics, thereby maintaining and ensuring social identity.

Researchers of collective remembering define it as keeping alive shared emotions and representations, with which it also encompasses traumatic events and searches for ways to react to these experiences as memory and include them in the group identity - e.g. Confino, 1997; Olick, 2003; Rosenfeld and Jaskot, 2008; Suleiman, 2006; Bar-Tal, 2014; and others. Collective memory comes to life again if there is pride in the remembrance of a victory. But did the Latvians celebrate victory in 1945 ? Yes and no, because the war had ended, and a part of the Latvian soldiers greeted the end of the war along with the victors. But for the majority of the population, the end of the war brought a new occupation to their country. Memories of the war hindered the recovery of balance, and it took great effort for people to regain a sense of balance. The war resulted not only in the loss of statehood; it also involved a demographic occupation of Latvian territory (the Baltic Military District headquarters and Soviet army troops were based in Latvia, and civilians from across the USSR were also brought in and settled in Latvia).

Along with the new occupants, a variety of collective memories also entered Latvia, including memories that the repressive Soviet regime prohibited to be publicly expressed [7]. In the Soviet Union, the state determined and controlled memory policy, and this required silence regarding the victims of Stalinist repressions as well as the many, many victims of the war and all the lives destroyed and maimed by the war. All of these memories were banished from the state-sanctioned story of victory. The situation was particularly harsh in Russia itself, because many of the social and political shocks the country had experienced in the 20th century had been self-generated; repressions and threats were not the only reason for the people's silence, and personal sorrows had no broader regulation [8]. Therefore, celebration of the official Victory Day with a public commemoration ritual became a mass stand-in for sorrow. The regular celebration of Victory Day began only in $1965-$ and according to the Soviet "calendar", on May 9th - in order to highlight the Soviet Union's merits in the victory. The story of the war became and remained collective property and was opened to reinterpretation only after the Soviet Union disintegrated. Only after 1991 could relatives receive information about their loved ones who had suffered repressions. Such controlled remembering was linked to a denial of private loss and pain and was a brutality inflicted by the Soviet system. The military parades on May 9th were planned to drown out the pain of individual memories - the war, no matter how dreadful it had been, was reframed as the collective triumph of the survivors [9].

National history is taught and developed during the socialisation process and cemented with specific memorial rituals. Social psychologist Daniel M. Wegner describes memorial sites and dates, and the culture of remembering in general, as elements of a transactive memory system that exists as the result of communication between individuals [10]. He describes memory as a "form of transportation" that is in constant motion, forming connections between individuals. James Wertsch, for his part, highlights language as a transparent expression of collective remembering, which creates stories that inspire people to follow their example. Wertsch also explains that the Soviet Union created narratives for the media to disseminate to individuals and groups in order that they might understand them and the state. $\mathrm{He}$ calls this situation "one-voice official collective remembering", which was created by the Soviet education system, media, ideology, repressions and fear [11]. The totalitarian state did not allow differing views regarding historical events; it also excluded individual independent views and interpretation of such events.

The Second World War ended 70 years ago, but memories of it are still very much alive. Susan Sontag compares memory to an infection; she believes there is no collective remembering and that all memory is individual and unrepeatable and dies along with the person. She believes that what we call collective remembering is actually an agreement - guidelines that have been agreed upon regarding what and how we remember something. She gives memories a communicative role as well, meaning that they can be written down and transmitted until they are known by all family members [12]. But the landscape of memory in a society is never so uniform; it contains many and varied plots and experiences. However, after regaining independence, the heritage of the Second World War created two different memory cultures in Latvia. One of these cultures was that of the victors, who inherited the identity of the Soviet person as 
victor. The second culture was that of the citizens of an occupied territory, and this was a traumatised identity marked by the loss of a nation and fighting on the wrong side.

\section{Memory Groups and Rituals of Remembering}

Each year on March 16th and May 9th, Riga becomes the site of two groups performing rituals of remembering, two groups that have confronting versions of history and generate contradictory impulses towards the Latvian state. The commemoration rituals of both groups are based in historical references - one group won the war and celebrates this victory and commemorates its dead at the foot of one of the city's monuments, while the other group, who fought on the losing side, ought to commemorate its dead at the Military Cemetery but have instead chosen a more visible format in the form of a march by the Freedom Monument in central Riga. Both memory groups gather at a monument signifying its era - the Legionnaires meet at the Freedom Monument, which was built in 1935, and financed by citizens' donations and bears the inscription "For the Homeland and Freedom", while those celebrating Victory Day meet at the monument to the liberators built during the Soviet occupation in 1985. Both memory ritual groups tell about their experience of history, thereby upholding and cementing the group's social identity - one group does this by celebrating, the other by accusing.

Each year, the city prepares for these two events, especially March 16th. Metal barriers are erected by the Freedom Monument, and many policemen accompany the march in central Riga to ensure the participants' safety. Even though there are no metal barriers at the May 9th event, the large number of participants demands a heightened police presence. Visually, both events exude tension, and their design alone points to conflict...not only in the urban environment, but in the very understanding of history. On March 16th, people who receive their information from Russian-language media come out to express their disappointment, because this event is heavily covered in the Russian media, where it is called a "Fascist march" (it has become a common practice in the Russian media to use the word Fascist incorrectly, a practice that is then also often adopted by European media sympathetic to Russia).

Latvia is not the only country in Europe where people publicly commemorate their Second World War dead, even if they fought on the losing side. The Legionnaires' march has been taking place in Riga since 1992. At that time it signified the regaining of public respect for those Legionnaires who had survived; it was their way of demonstrating that they had fought not only in Germany's interests but also in Latvia's interests, which is why the commemorative event takes place at the Freedom Monument, a site with great cultural significance to
Latvians. In the early 1990s leading government figures also took part in the march, but under the pressure of international scrutiny, this attendance decreased by the end of the decade. This marked a break in Latvian collective memory - the human right of commemorating their dead on March 16th (the anniversary of the first battles against the Red Army) was not intended for the losing side. The double standard of "big history" forced the Latvian parliament (Saeima) to state a political position. Thus, on October 29, 1998, the Saeima adopted a declaration that concluded with the statement that the responsibility of the Latvian government is to 1) demand from the occupying nations and their legal successor states that, subject to the rules of international law, they pay compensation to Latvia's citizens, their family members and heirs for losses they incurred as a result of their illegal mobilisation into the armies of the occupying states; 2) safeguard against the violation of the honour of Latvian soldiers in Latvia and abroad [13].

With this declaration, the Saeima clearly stated the government's position regarding Legionnaires. However, since 1992, when the first former Legionnaires' march took place, the issue has remained open for Latvian society in general, namely, how should society respond to this fact of history and the memories of hundreds of thousands of people? Vita Zelče, a Latvian researcher of social history, believes that the arrival of this social memory in the public sphere was very crucial and very welcome for a certain part of society. The decades of keeping silent, the accumulation of resentment and wrongs, gave it particular force [14]. Memories that had been silenced and repressed for decades broke out into public commemoration. The March 16th march is quiet and sorrowful, because the victims died in vain (because statehood was not regained). Along with the discussions in society and the media, ever more publications and informational materials began to show up about the Legionnaires who ended up in Germany at the end of the war, and in the public's opinion they were seen as fighters against totalitarianism. After all, former Latvian and Estonian Legionnaires had worked as guards during the war tribunals in Nuremberg [15]. Not only did former Legionnaires take part in the March 16th march; more and more people from the younger generations also began to attend the march in honour of their ancestors. While the "forgetting" or "denial" of history means the deliberate suppression of memory, this is usually not possible when it comes to collective remembering [16]. The Legionnaires' commemorative day has also become a day of criticising the government's perceived excess of political correctness.

March 16th and May 9th illustrate a memory conflict, a conflict that has become ethnically exclusive (ethnisation of memory) and a subjective, psychological reality with separate symbolic components. These two collective memory ceremonies belong to separate ethnic groups within society and reveal an unresolved conflict, because historical events are being transferred to the present day. They bring to light the fact that there exist two competing societies in 
Latvia - the victors liberated Latvia from Nazism, but they remained in the country, which they see as theirs, their spoils of war. For many years, until the restoration of independence, the losers were forced to accept and participate in a "local" government organised by the occupying regime. Now independence has been regained, but the victors' commemoration site still exists, around which the victors' memory and identity is centred and consolidated. The unresolved memory conflict includes some of the master narratives of conflict, which dramatically differ from each other [17].

\section{Inspiration for Hypothetical Dialogue}

Inspiration for these thoughts came from the life story of history professor and Second World War veteran Pēteris Krupnikovs, who fought for the Red Army in battles by the Daugava River in the Jēkabpils/Krustpils area of Latvia. During one interview, he interrupted his narrative about the war to tell me about an incident that happened 20 years ago at a library in Germany. He had ordered a copy of a book, and the person working behind the desk was a man of approximately his own age. Having looked him up and down and, already knowing the professor was from Eastern Europe, the man asked Krupnikovs whether he had fought in the war, because the library employee had also fought on the Eastern front. After a bit of conversation, the two men realised that they had fought in trenches on opposite sides of the very same battles along the Jekkabpils-Krustpils front line, right across the Daugava River from each other. In essence, two former enemies had now met each other face to face in a library. The German's reaction to the coincidence was simply, "Well, that's worth a cognac, isn't it!?" And with that, an important episode of life experience had come to a close. After so many years, two former enemies were able to have a friendly conversation.

This episode of Professor Krupnikovs' life story revealed the bounty of humanity and culture that people should be reminded of, namely, that behind the ideologies, prejudice and ignorance we must retain the ability to see that another person's life has just as much value as our own. The meaning of the big events in history is to create a repertoire of memories (faith, relationships, emotions) through which those events can be evaluated. The professor had fought in the Soviet army; his former enemy had fought for the Germans. Both veterans had stepped beyond the social concept of collective remembering, which legitimises the demonisation of an enemy - the war had ended, and it was time to seek out points of contact in their respective experiences, even if those experiences had once been directed against each other.

Inspired by the professor's story, I decided to see if a dialogue was possible, if only hypothetically, between two life stories. In interviews with participants in the March $16^{\text {th }}$ and May $9^{\text {th }}$ event, I asked how they see and comprehend not only themselves but also the other side's memories and ability to commemorate their dead.

A certain split can be seen in Latvian society today. It is not only a matter of different collective memories; the society is also split linguistically, with a third of the population being native Russian speakers, and their media space is oriented towards the Russian worldview and politics.

In preparation for this study, I chose the neutral approach of using life stories, which helps to provide a balanced view of people's experience, values system and self-comprehension.

We live in a functionally differentiated society, in which a unified centre determining self-comprehension has been more or less lost; the centre from which society's self-description is formed is also disappearing. We try to avoid generalisation in everything from our daily awareness to academic studies, and still, according to sociologist Niklas Luhmann, it is important for society to seek out descriptions that unite possibility/impossibility. Because one experience can lead to the opportunity for it to be enriched with an explanation that can be used for much more complicated matters and make it more understandable, despite growing contradictions, and even if it doesn't bring immediate clarity regarding the processes that researchers observe [18].

Society's idea about itself is created by history, cultural stories, including literature, and also each and every person's vision about his or her own life. Latvia's history is complicated and contradictory; it is dominated by the story of the loser, documentation of which can be found in the National Oral History (NOH) collection. Of course, the $\mathrm{NOH}$ collection also includes plenty stories of personal victory, but Latvian society as a whole tends to be fairly resigned about history. From victory in the War of Independence and the creation of their own nation, until the time when bitterness and disappointment show up in the life stories regarding the failure to safeguard independence in 1939-1940 as well as the subsequent era of Stalin's Terror and the resulting arrests, persecution and deportations [19]. In the 1950s Latvia experienced the persecution of its National Communists, and in place of Khrushchev's "thaw" it experienced a mass industrialisation of the country and the bringing in of manpower from other parts of the Soviet Union. These events caused a continuous downward spiral of political failures. Of course, ordinary people continued living their lives under such circumstances, and in their memories they shrug it off, saying this was their youth, and they lived life as best they could. However, a public "veil of forgetfulness" covered many historical events as well as the complicated relationship with history. It is difficult to find a family in Latvia today that was not in some way touched by the war; it was not uncommon for members of one family to have been pulled into the war on opposing sides. As a researcher, this was a new experience for me, because my own family's experience was exactly the same, namely, two brothers were forced to fight against each other in opposing armies. Less known to us are the life stories of those who celebrate May 9th, their experiences with the war and how 
they ended up in Latvia.

Deirdre McCloskey has always stressed the fact that culture consists of "the telling of stories", because with stories we create, remind and coordinate society's understanding of itself...or they introduce silence, or create changes. "Stories are told" not only in literature and the arts; economists, politicians, the media and human culture in its broadest sense are also all story tellers [20]. This relates to Émile Durkheim's statement that we live surrounded by cultural stories and cannot tell about ourselves without this cultural context, without language, history and experience. Language, which we inherit from previous generations, is a part of our identity. A language can be learned, but the speaker can nevertheless remain outside the culture in which he or she lives. History, too, can be learned but not personally accepted as one's own. What about one's own experience? How do language, history and experience grow into identity if the person in question no longer lives in his or her ethnic homeland? These are questions that arise in the present study. When listening to life stories, language is important - the ambiguity of language (vocabulary, word choice) as well as the narrator's intonation, which not only tells a story but also opens the opportunity to understanding, all deserve the researcher's attention.

The present study is based on two life stories, which were obtained by attending two events: the Latvian Legion commemoration on March 16th and the Russian celebration of Victory Day on May 9th. Using the participant observation method, I randomly obtained two stories about life experience that explain the narrators' participation in the above-mentioned events. In the interviews I also searched for an answer as to how these people see and understand one another. In other words, is a dialogue possible between these two life stories?

\section{The March 16th Participant's Story}

We met for the interview a few days after March 16th, when impressions from the event had paled a little and my interviewee's life story alternated with oral history, as he remembered what he had experienced and understood of the last segment of the war. This participant of the March 16th march had been an only child born into a patriotic family. He had received a good education and become a professor. I've listened to his story several times to understand his thoughts about the events of that era and how he sees the situation today. His voice and intonation betrayed pent-up emotion as well as a certain bitterness and disappointment. He told about the history of Latvia's 20th-century battle for independence, particularly stressing that non-resistance - albeit in the face of significantly larger military superiority in 1939-1940 - is still a big problem today. He said that he often thought about what happened and could have happened, and therefore he saw March 16th as only one link in a long chain of betrayal and cowardice:
For me, March 16th is a day of commemoration, because I saw all of that up close and felt the hope we had during the German occupation. How the men consoled each other, saying we'd have weapons, that we'd be able to secure [Latvia] here. I think there must have been some sort of betrayal, because the 19th Division was supposed to retreat through Riga, but it was diverted elsewhere. The Estonians succeeded; they had an independent government for a few days before the Russians came in again. But afterwards all that was forgotten, because it wasn't advantageous to the Allies back then; it was all "rolled into the asphalt".

The life story then turns into oral history, because the narrator's opinion about the final segment of the war, about the Kurelians (Kurelieši) [21] - who, in his mind, are a completely different story than the Legionnaires - enters the story. He tries to remember but doubts the precise date; he thinks it may have been in 1943 that the German occupying forces allowed the local national guard organisations to be renewed and wear their own uniforms. The guardsmen are even said to have given oaths of allegiance to the Latvian army. Of course, they also included men who were in the German army. And he adds that to this day the actual truth has not yet been determined. The Kurelian leadership was shot on the beach in Liepajja; Upelnieks, too, whom I sometimes saw visiting at my father's house. The 19th Division stayed here. Everything should have been different... [a long pause] And therefore, for me, this day [March 16th] is a day of commemoration for all of those who died.

When I think about what's happened to us over the course of history that we've always had to fight under foreign flags that we haven't managed to secure our own country. For me, it's a day of contemplation about all the Latvian soldiers who died unfairly, who had to fight in opposing armies. I think about the Latvian Riflemen regiments in the First World War, when appeals to patriotism were also made, and all of them died, too. I think about the betrayal against Latvia in 1939. If all three of us Baltic States had resisted...who knows.

I wasn't there at the battles of March 16th, but for me it's a day of contemplation about the fate of our people. It doesn't refer to anything specific, but it is important to me, when thinking more broadly about the fate of our people. That's what our torn-up history is like, and therefore March 16th is a day of commemoration for me.

This narrative brings to mind other episodes as well, for example, why didn't all three Baltic States manage to unite at the beginning of the war and show resistance together with the Finns? Then no one today would dare say that Latvia joined the Soviet Union voluntarily.

For me, March 16th is a day of contemplation, because even though I didn't personally take part in those 
battles, it's important for me to be together with everyone on this day. I know we would have been happy to be wearing Latvian army uniforms and fighting for our country.

When asked his thoughts about the May 9th Victory Day celebration in Riga, my interviewee admitted that there's nothing more we can do today to change the situation. In 1990 the Latvian government accepted an agreement that allowed Russian officers and their families to stay in Latvia. Today, the people who gather on May 9th are under the influence of the Russian media. When asked whether he saw any chance of settlement between those who fought on opposite sides in the war, he answered:

First of all, we needed to send all the Soviet army officers and their families back to Russia in the early 1990s. The delegation that held the discussions with Russia back then must take responsibility. The monument should have been demolished immediately after independence, just like we did with the Lenin Monument. We should have built a beautiful building there, for example, a concert hall. But there was fear back then. Now it's too late, and there's nothing that can be done anymore. Is a settlement possible? People are being nudged by both sides. In the West, it's all kind of covered with the statement "Well, that's what happened, and it's over now". But here it's used by both sides, and the Russian apparatus uses it. We still have former Russian officer organisations here - our security forces see this, but they remain silent. Actually, they [the Russian officer's organisations] are the biggest force; they're waiting for their hour. That's our misfortune, that Riga was the centre of the Baltic Military District. It was even planned for us to begin using the Cyrillic alphabet here in the late 1970s, to create the 'Pribaltiyskaya respublika'. In his terse statements he expressed years and years of thoughts about the repercussions of the Second World War in Riga, and every year these thoughts ripped open the old wounds again. They also raked up memories about the threat of Russification in the late 1970s. During our conversation, he paused many times. The longest pause came before the topic of a settlement with history and the celebrators of May 9th: ...but the main thing today is to not start hating.

The march on March 16th, 2011, met with much noise and opposition at the Freedom Monument, opposition organised by the so-called anti-Fascists. This was the first time I had attended the Legionnaires' commemoration event, and my method of participant observation did not allow me to distance myself from my topic of research. The aggressive shouts, the police cordon and the metal barriers were evidence of intolerance and confrontation. A dialogue is only possible in a democratic and tolerant society, and therefore it was with genuine interest that I awaited Victory Day on May 9th, which is celebrated by Latvia's so-called
Russian-speaking community. There I hoped to meet a respondent who would speak to me about May 9th, in order that I could continue my search for the possibility/impossibility of a dialogue between the two sides. Is it possible to find a common thread between different memories and life story experiences?

\section{Victory Day}

The day was sunny and warm. Crowds of people flowed towards the monument, task of research were to find out respondents. A small conversation with a young couple who were also heading to the Liberators' monument with flowers in their hands. I asked them what this day meant to them. But our conversation did not flow well, because they detected an accent in my pronunciation of Russian and said they didn't speak Latvian well. They did not allow me to turn on my recording device and said they were coming here to remember their grandfathers, who had died in the war. Their answers were elusive, and they did not wish to continue speaking with me. I then asked several war veterans about possible interviews at a later date. Some of them gave me their telephone numbers, but they did not answer when I tried calling. I understood they did not wish to speak with me.

After some time, however, I did manage to reach by telephone a woman whom I had spoken with on May 9th, and we arranged to meet so that I could record her life story. She arrived slightly apprehensive but open to a conversation; it seemed that she was used to the attention of journalists in conjunction with Victory Day. She began her story with what seemed like a previously rehearsed text and eloquently told me about her childhood. She was her parents' seventeenth child, and life for the family was hard. They had a wooden house and small garden near Nizhny Novgorod. During the war, and right after finishing school (at age 17), she was drafted into the Soviet army. When asked whether she was afraid, she said, No, I wasn't afraid. My mother died before the war, and my father died before I was born - I had already been hardened by life. In Gorky we defended the automobile factory from an air attack. Her story does not contain many details about wartime, but it does make it clear that the war was even more merciless than the loss of both parents in forcing her to grow up quickly. She continued: When the front line approached Riga and we liberated the city, I remained here. I was very sick. I had contracted malaria during the war, and the doctors didn't believe I would survive. But they took me along to the front lines anyway - if I was fated to survive, I'd survive; if not, then I wouldn't survive. I was so weak after the malaria that I remained here [in Latvia].

A slight feeling of alienation can be heard in her voice; she tells about her life without any emotion, in a very matter-of-fact way. Is this because she has told about her wartime experience many times before and she's hardened herself to it? Or is it the story of a victor - the story of herself and the circumstances that could not break her? But after the 
war I did go live with my sister in Moscow, who lived with her family in a small, 15-square-metre apartment. We were six people living there. I slept under the table because there was no other place to sleep. And so I stayed there, until my sister's family began to argue amongst themselves. It was really narrow living there, and so I decided to return to Riga.

When asked about her experience of settling in Riga, whether it was difficult, and whether she felt that it had been a different country before, whether she felt she had arrived in a foreign country, her answer surprised me: No, no one had taught me that this had been a different country before. No, we weren't taught in school, either, that there had been a Latvian state. I never felt anything like that. No one bothered us, everything was calm here. But later she remembered that the army authorities had taught them, had given them strict orders, to never enter a house where they did not known anyone, to be as careful and clever as possible. She had forgotten about the post-war instructions about how to behave out in public and how to behave towards the indigenous population (a Soviet-era term). Was she the only one, or are there many like her, who arrived in Latvia and walked around Riga as if it were a part of the Soviet Union or is this some kind of learned amnesia to not remember that which is traumatic or unpleasant? The frankness of my interviewee's narrative makes one believe that she really did not know that Riga had been the capital of an independent Latvia before the war. Ignorance of history brings to mind German author Bernhard Schlink's novel The Reader (Der Vorleser) [22]. But my interviewee has a secondary education, and therefore the comparison with the illiterate Hanna is out of place. Still, ignorance or the lack of independent thought, which was characteristic of the Soviet education system and totalitarian systems in general, can be taken as a justification of sorts for her returning to live in Riga.

In just as stern and dutiful a voice she also told about meeting and marrying her husband in Riga. I lived well, because my husband was an army man and earned a good salary. I was secure. I also lived in a communal apartment, sometimes I also tried speaking Latvian, but the reaction was 'you don't have to, we want to speak Russian'. People were forced to live in communal apartments, even long after the war, and thus they had to learn to live with people who had differing worldviews and values. Communal life brought a typically Soviet style to life - the tone was a set by the victors' bearing, language and understanding of sensitivity. The post-war Stalinist terror and subsequent destruction of Latvia's National Communists created situations, not only in communal living arrangements, in which equal relationships were unimaginable.

The victors' psychology is stable and consistent. My interviewee continued: In 1990, when Latvia gained independence, I was at a class reunion in Russia. Back then, I was militantly minded and, regarding Latvian independence, I said that 'we beat the Fascists once, and sooner or later we'll show them again...' But if the victor turns out to be someone else, if big politics changes the usual order of things, then she was willing to admit: But now the politics here are different. So we have to accept it. Since Latvia became independent, some of my neighbours in my apartment building respond in a friendly manner to my 'labdien' [hello], but others don't. People are different - that's not connected to ethnicity.

When asked about the Legionnaires, she took the position that Well, the Legionnaires, they've killed so many people. When I commented that during the war people on both sides killed, some emotion finally entered her speech for the first time in the interview: I don't like these moves, they're always being shown on television. When I asked whether the march disrupters, who carried impaled pigs' heads and Nazi symbols, were also shown on television, she said that she did not see anything like that. She changed the topic and talked about her feelings: In 1997 the atmosphere here was such that I wanted to return to Russia, but I didn't really have anywhere to go to - I have practically no relatives left anymore. Because the situation here was such that there were rumours in the newspapers and on television that the Russians would be deported. One of my neighbours translated from Latvian, where it was written that there were going to be deportations. Well, if they were going to deport us, then let them deport us.

In order to lessen the tension that had developed in our interview, I asked her thoughts about March 16th as a day to commemorate the wartime dead. Well, the government lets them do so. When Vaira [Vikke-Freiberga] was president, she prohibited the wearing of Victory Day medals in public. But no one obeyed; everyone wore them. When Vaira saw that the prohibition wouldn't work, then [President] Zatlers didn't pay any attention to those issues, either. I asked her which television channels she watches: Only First Baltic Channel and Moscow News. I'm not interested in Latvian news or culture. On May 9th I always go to the monument, and I also go to the Moscow House - there's usually a concert there. But when I asked again about whether the Legionnaires have a right to commemorate their fallen soldiers, she sighed and said, yes, the dead must be remembered.

\section{A Dialogue of Stories against the Backdrop of Memory Conflict}

Could these two stories converse with each other, and, if yes, how? Does research have the resources to obtain a "third voice", a voice of cooperation, as formulated by Barbara Meyerhoff, I use her concept of the "third voice" to create an approach to a dialogue between these two life stories, to develop an ability for them to speak with each other, because, after all, they live in the same country. Do conflicting experiences and memories have a future within the borders of one country? Both groups maintain a social memory complete with stories of destroyed lives, lost lives, family tragedies and wartime victims. These stories are taught to the next generations; they are like wartime "wounds" that are 
passed on into the future; they live in the same country, sometimes even next door to each other in the same apartment building. The inheritors of these stories buy groceries at the same stores, but they watch different news channels.

The question remains of how, in studying two life stories, to retain a neutral position if the researcher belongs to one of the two communities studied. How can he or she achieve this third voice, this voice of cooperation, between the two stories, between March 16th and May 9th? A dialogue is a positive possibility that was impaired by the 2012 referendum on the introduction of a second official language in Latvia as well as conflicting collective memories. The commemorative rituals on March 16th and May 9th continue to divide the population.

Sociologist Niklas Luhmann stresses that society's development and renewal is determined by communication, although we can also often speak of non-communication. Nevertheless, we must keep in mind the possibility of dialogue as an important moral obligation that would lessen risk.

The two life stories I heard in connection with the above-mentioned events do not provide any clear answers about whether a dialogue and an understanding about the past are possible between people who fought on opposite sides and who still regard the place they live in so differently, even so many years after the war. For one group, this is a liberated land and their spoils of war; for the other group, this is their only homeland and state, a country that was unable to defend itself at a critical moment. Are there any points of contact behind the victors' bravado that would allow the losers to obtain solace in a public commemoration ceremony?

Daniel Bar-Tal indicates that, from the moment a society begins studying the causes of unresolvable conflicts, someone always turns up who does not wish to take part in the reconciliation. For some, this might be the demonised Legionnaires, who "want to deport the Russians from Latvia". For others, it is Russian politics and the wish to maintain a divided collective memory [23].

Latvian independence changed the participants at the May 9th event; citizens who see the Soviet regime as having been an occupying force no longer participate in the event. The Victory Day participant whom I interviewed, however, was surprised that the Latvians had changed their attitude towards the liberators, because up until now we were handed flowers and told 'thank you' for the liberation. The social concepts of collective remembering reflect the positive, praiseworthy in-group characteristics created by the Soviet system. Only in the last decade have studies about the brutality and violence of the Soviet armed forces in the territories it occupied reached the Western intellectual tradition [24]. The Soviet history tradition taught people to see and remember only the atrocities carried out by the Nazis, and to forget its own atrocities. Remembering and forgetting are two parts of the same process with which an authoritarian society attempts to manipulate, and also indoctrinate the young generation through the educational system. Both conflicting memory groups pass their memory and identity stories on to the next generation, thereby diminishing the hope that the memory conflict will disappear any time soon on its own.

The Legionnaires' collective memory, for its part, depicts its group members as sufferers and victims. They fought on the losing side, they survived Stalin's penal camps and the humiliation of the Soviet system. Added to this are the memories of the Swedish government's decision in 1946 to give back to the Soviet Union those Legionnaires who had fled to Sweden as refugees. Formally, collective remembering is directed more at victories or losses; therefore, in-group memory reformulates a term like the Courland Cauldron, used in the Soviet historiography, into the Courland Fortress, because the Legionnaires' battles in Courland provided supplemental time and opportunity for those Latvian citizens who did not want to experience a third occupation of their land to escape into exile.

However, for those who celebrate Victory Day, May 9th is also a day to commemorate their own dead; it is an opportunity for them to remember all of the victims of war, because the Soviet side actually suffered the greatest human losses in the Second World War. The Soviet regime spatially marked memory in all of the territories it gained after the war with large commemorative monuments; for the ethnic Russians who arrived in Latvia after the Second World War and in later years, this monument became a site for confirming their identity in Riga. It was a place where they could lessen the trauma that arose one morning in 1991 when they woke up no longer in a republic in the western Soviet Union but in an independent country called Latvia.

Thus we obtain several backdrops for two warring memory groups that can be added to the dynamics of collective remembering, in which one group was robbed (during the Soviet era) of the opportunity to publicly represent its collective memory and commemoration. This situation changed when Latvia regained its independence with their public ceremony of collective remembering in central Riga, the Legionnaires keep the discussion in Latvian society keen and alive, because the formerly silenced memory has once again become uncomfortable due to standards of political correctness.

Both collective memory groups fill a need for memory and remembering, because each person's death in the name of the homeland is worthy of remembrance and respect.

\section{Conclusions}

In the epilogue to the book Memory, History, Forgetting, titled "Difficult Forgiveness", Ricoeur writes that the issue of representing the past in the portrayal of history is linked with the risk of forgetting history. Such a situation creates a double effect: first, it is the concealment of blame, which paralyses the power to act and be who we are; second, it is like the answer to an existential possibility, which is 
described with the term "forgiveness". Ricoeur believes that blame and forgiveness are like a double secret that weaves through the portrayal of history. First, as an effect of blame, where it is crossed by forgiveness in important historical memories, if blame provides a foundation for the possibility of forgiveness. He stresses that forgiveness is difficult to achieve and receive, and it is even difficult to imagine; but forgiveness can happen if the wrongdoer asks to be forgiven [25]. Victors are not tried; Russia has not experienced the awareness of blame and self-reflection that Germany experienced after the war. It seems that Russia's critical awareness of its own history is moving ever further into the unknown future.

The stories of the narrators are ethnocentric and stable in the sociological truths of their respective groups.

Life stories show differing self-understandings - victors versus losers. In any conflict, each society is interested in maintaining a unified stance that gives its participants conviction about their sense of belonging, because conflicting memories, especially in the realm of national narrative, can weaken national safety. European history shows that societies have had to use formal and informal mechanisms to keep society's collective memory whole. How is that possible in the case of Latvia, where each of the memory groups tries to convince the international community that its narrative is the true one? In the Russian ethnic homeland, the Second World War narrative has had an abrupt break - the law now dictates how people must write about, talk about and remember what persists to ideologically be referred to as the Great Patriotic War. After the openness of the 1990s, Russia is now able to maintain a selective, subjective and distorted memory in its countrymen living in neighbouring countries - we were attacked, we defended ourselves, the paradigm has remained unshakable.

Only one common reference in the two above-studied life stories, namely, that the war destroyed the lives of their loved ones and themselves, that there are no winners or losers in war. But the narrators' own voices remind us that there nevertheless are winners and losers - the voice of the participant in the May 9th celebration changed when she remembered 1991 and the declaration of Latvian independence; she was in Russia at that time, and when she heard the news, she militantly promised her friends that she would deal with Latvian independence. Her story reminds us of James Wertsch's concept of the "one-voice official collective remembering" created by the Soviet system, its media, ideology, repressions and fear [26].

A dialogue can begin if both sides have become well enough acquainted with the newest findings in history and have had a chance to reflect upon their own experience. Theoretically, the two interviews examined above show that the present study has obtained two separate objects that are connected only outwardly, on the surface (that is, they are connected by the fact that they exist in the same space, in the same country). Therefore, the question remains of how to create a self-description of society if that society consists of countless individual self-descriptions that are often in conflict with each other. Through life stories we meet people at different levels of complexity regarding moral choice, which puts not only their values to the test. Luhmann is convinced that prudence is an individual value, and it includes a kind of reflection that can offer unifying references to society as a system and thereby lower risk.

This paper has tried to illustrate the need to approach the history of war and remembrance of war from the angle of small-scale, locally rooted social action.

\section{Sources}

Interview with participant of commemoration of 16 March done at March 30, 2011 in Stockmann cafe Riga - man of age 80 , University educated, will stay anonymous.

Interview with participant of Victory Day at the 9 May done at August 3, 2011, at the Institute of Philosophy and Sociology (building Academy of Science) - Jelizaveta Konstantinovna, of age 80, high-school education, has interview experience for Russian speaking newspapers.

\section{REFERENCES}

[1] Snyder T. Bloodlands: Europe between Hitler and Stalin. N.Y.: Basic Books, 2010.

[2] Ibid., Epilogue.

[3] Ibid., Epilogue.

[4] Vingolds, I. Latvijas īpašās brīvprātīgo vienības 1991. gada barikādēs. Nevardarbīgās pretošanās Latvijas pieredze (Latvian Special Volunteer Units on the Barricades in 1991: Latvia's Experience with Non-Violent Resistance). T. Jundža and R. Zaļā (eds.) Rìga: LZA, 2006: 247-253. [On June 17, 1989, 522 former soldiers who had fought with the 43rd Latvian Riflemen Guards' Division and the 130th Latvian Riflemen Corps, as well as former soldiers of the 15th and 19th Latvian Legion Divisions, met in the Great Hall of the University of Latvia. The goal of the meeting was to reestablish the Latvian army.]

[5] Kacena V. Kājāmgājējs karā. Latviešu kara stāsti (A Pedestrian in Wartime: Latvian War Stories.). Rīga: Mansards, 2012. Dialogā ar vēsturi. Pētera Krupņikova dzīvesstāsts (A Dialogue with History: Pēteris Krupnikovs' Life Story). Rīga: Zinātne, 2015. See also: Nesaule A. A woman in Amber. Healing the Trauma of War and Exile. N.Y.: SOHO, 1995; Eksteins M. Walking since Daybreak. A Story of Eastern Europe, World War II, and the Heart of Our Century. Mariner Books, 2000; Kalnins M. Latvia: A short History. London: C. Hurst \& Co, 2015.

[6] Karojošā piemiņa. 16. marts un 9. maijs (Warring Remembrance: March 16 and May 9). N. Muižnieks and V. Zelče (eds.). Rīga: Zinātne. 2011, p. 398; Neiburgs, U. Dievs, Tava zeme deg! Latvijas Otrā pasaules kara stāsti (God, Your Land is Burning! Latvia's Stories of the Second World War). Rīga: Lauku Avīze, 2014.

[7] Merridale, C. War, death, and remembrance in Soviet Russia. 
In: War and Remembrance in the Twentieth Century. J. Winter and E. Sivan (eds.). Cambridge University Press, 1999: 61-83.

[8] Winter, J. and Sivan, E. Setting the framework. In: War and Remembrance in the Twentieth Century. Edited by Jay Winter and Emmanuel Sivan. Cambridge University Press, 1999: 6-39.

[9] Merridale, C. War, death, and remembrance in Soviet Russia. 1999: 61-76.

[10] Wertsch, J. V. Voices of Collective Remembering. New York: Cambridge University Press, 2002.

[11] Wertsch, J. V. Voices of Collective Remembering. New York: Cambridge University Press, 2002: 67-68.

[12] Sontag S. Regarding the Pain of Others. New York: Farrar, Strauss and Giroux, 2003: 85-86.

[13] Latvijas Republikas Saeimas Deklarācija Par latviešu legionāriem Otrajā pasaules karā (The Saeima of the Republic of Latvia Declaration Regarding Latvian Legionnaires in $\begin{array}{lllll}\text { World } & \text { War } & \text { II) } & - & 29.10 .1998 .\end{array}$ http://www.saeima.lv/steno/st_98/st2810.html_ [Saeima Transcript Archive, October 29, 1998, Latvian] (last viewed 24.01.2016).

[14] Zelče V. Latviešu legiiona atmiņa un piemiņas dienas Latvijā sākotne (Origin in Latvia of the Day of Commemoration and Remembrance of the Latvian Legion). In: Karojošā piemina. 16. marts un 9. maijs (Warring Remembrance: March 16 and May 9). N. Muižnieks and V. Zelče (eds.). Rīga: Zinātne. 2011: 134 .

[15] Ezergailis A. The Latvian Legion: Heroes, Nazis, or Victims? A Collection of Documents from OSS War-Crimes Investigation Files, 1945-1950 (Riga: Historical Institute of Latvia, 1997). The Latvian SS Voluntary Legion remains a controversial part of Latvia's past under the Nazi occupation. Although there was a short period during which enlistment was voluntary, the response was insufficient for the military needs of the Nazi regime. Thus, in February 1943, men born between 1919 and 1924 were drafted, which was then expanded to those born between 1906 a 1926. The 15th Division was the first to be established and fought first in Russia, then in 1944 in northern Latvia. In 1944 it was sent to Pomerania, where in 1945 it found itself in the U.S. and British zone. The 19th Division fought primarily in Kurzeme (western Latvia). In 1945, most were sent to Siberia by the Soviet regime. Many Latvians saw, and continue to see, the Legion as the only opportunity to participate in the battle against the Soviet Union and saw a fight against Germany as the next step that would free Latvia. The Legion as a whole did not participate directly in the murder of Latvian Jews; however, it is known that individuals who had been part of the killings later joined the Legion. From: Andrievs Ezergailis, Latviešu legions: Varoni, nacisti vai upuri? (The Latvian Legion: Heroes, Nazis, or Victims?) Riga: Latvijas vēstures institūta apgāds, 1998, pp. 9-14. See also: Mirdza Kate Baltais, The Latvian Legion: Selected Documents. Toronto: Amber Printers and Publishers, 1999; Inesis Feldmanis, "Latviešu un citu nevācu tautu ieroču SS vien̄̄bas Otrajā pasaules karā: Kopīgais un atšķirīgais" (Latvian and Other Non-German Waffen-SS Units in the Second World War: Similarities and Differences). In: Latvijas Vēsturnieku komisija et al. (eds.) Okupācijas režīmi Latvijā: 1940.-1956. gadā: Latvijas Vēsturnieku komisijas 2001. gada pētījumi (Occupying Regimes in Latvia 1940-1956: Studies by the Commission of Historians of Latvia in 2001). Riga: Latvijas vēstures institūta apgāds, 2002, pp. 165-78; Mežmalis, A. M. The Latvian Legion: Information, Facts, Truth. Riga, 2008.

[16] Ladd B. Epilogue: The View from Berlin. In: Beyond Berlin: Twelve German Cities Confront the Nazi Past. G. D. Rosenfeld and P. B. Jaskott (eds.). University of Michigan Press, 2008: 297.

[17] Bar-Tal D. Intractable Conflicts: Socio-Psychological Foundations and Dynamics. Cambridge University Press, 2013.

[18] Luhmann N. Risk: A Sociological Theory. With a new introduction by Nico Stehr and Gotthard Bechmann. New Brunswick: Aldine Transaction. 2007: 230.

[19] Beitnere D. Musicology and Power in the Discourse of Soviet Latvian History and Musicology. In: Across Centuries and Cultures. K. C. Karnes and L. Sheptovitsky (eds.). Frankfurt/M: Peter Lang, 2010: 151-168.

[20] McCloskey D. N. Storytelling in Economics. In: Narrative in Culture: The Uses of Storytelling in the Sciences, Philosophy and Literature. London: Routledge, 1994.

[21] Biezais H. Kurelieši: Nacionālās pretestības liecinieki (Kurelians: Witnesses to National Resistance). Ugāle: Rubena fonds, 2011 [1991; 1997]. In his work, Haralds Biezais mentions betrayal and also evidence destroyed after the war by Soviet agents in order to determine the true events at the end of the war in Kurzeme (Courland).

[22] Schlink B. Der Vorleser (The Reader). Zürich: Diogenes, 1995 [German]. In the novel, the main character, Hanna Schmitz, worked as a guard in a concentration camp during the war. In the 1960s, when the perpetrators of the Holocaust are being brought to trial for war crimes, Schmitz is afraid of revealing that she is illiterate. The novel deals with the issue of whether ignorance - in this case, illiteracy - frees a person from responsibility.

[23] Bar-Tal D. Collective Memory as Social Representations. Papers on Social Representations, Volume 23, pages 5.1-5.26, 2014 [http://www.psych.lse.ac.uk/psr/ - last viewed 23.01.2016.].

[24] Olschewski B. "Freunde" im Feindesland. Rote Armee und Nachkriegsgesellschaft im ehemaligen Großherzogtum Mecklenburg-Strelitz 1945-1953 ("Friends" in Enemy Territory: The Red Army and Post-War Society in the Former Duchy of Mecklenburg-Strelitz 1945-1953). Berliner Wissenschafts-Verlag, 2009. Urban, T. Der Verlust. Die Vertreibung der Deutschen und Polen im 20. Jahrhundert (The Loss: The Expulsion of Germans and Poles in the 20th Century). München: Verlag C. H. Beck, 2004 [German].

[25] Ricoeur P. Memory, History, Forgetting. University of Chicago Press, 2004: 455. See also: Suleiman, S. R. Amnesia and Amnesty: Reflections on Forgetting and Forgiving. In: Crises of Memory and the Second World War. Cambridge: Harvard University Press, 2006: 215-234.

[26] Wertsch J. V. Voices of Collective Remembering. New York: Cambridge University Press, 2002: 67-68. 